\title{
Form Tobacco to Potato: The Land Use Change in Agriculture Activity of Farmers in Mount Merbabu's Slope
}

\author{
Gunawan \\ \{goenantro@mail.unnes.ac.id\} \\ ${ }^{1}$ Universitas Negeri Semarang, Indonesia
}

\begin{abstract}
Agricultural land management in the highlands, especially on mountain slopes, faces various obstacles geographically, ecologically, and socially. Geographically and ecologically, agriculture in the highlands is vulnerable to landslides and decreasing soil fertility. Socially, the people do not have sufficient land to cultivate because the land is limited. Although the land is limited, people try to maximize their land to earn good living. One of the strategies is planting crops that have high price in the market. Unfortunately, the market is volatile so that people haven't obtained good income as they expected. In order to earn a better living, people on the Merbabu's slopes are currently switching planting from tobacco to potato, whereas a decade ago tobacco was the main crop to get high income. Based on the current condition, this paper aims to describe how the new commodity triggers social transformation in the community.
\end{abstract}

Keywords: Agriculture, Farmer, Merbabu, Potato, Social Transformation

\section{Introduction}

Availability of land is a major factor in supporting agricultural activities. In communities living on the mountain slopes, the existence of land faces various geographical, ecological, and social obstacles. Geographical factors make land on mountain slopes vulnerable to erosion and landslides, while ecological aspects deal with climatological aspects. Even though it is in the rain and water catchment area, the availability of water for agriculture is very minimal since the agricultural land is cultivated in the form of rainfed land. The land in a mountainous region with an active mountain faces the possibility of eruptions at any time which can change the ecological order so that the land management system requires adjustment. Another obstacle is the types of plants that can be cultivated are also very limited. The social constraints faced by farmers on the mountain slopes are also fairly complicated. Limited land access and low levels of community welfare as a result of limited land productivity as a source of life needs fulfillment are the main problems. As a result, people are looking for other sources of livelihood in economic centers by leaving their domestic origin. As a result, villages in the mountains have become short of productive personnel to run agricultural systems. The level of community welfare is at a low rate, due to limitations in resource management, especially in the agricultural sector.

Although the agricultural system on the mountain slopes faces obstacles, various efforts to pursue agricultural productivity continue. Farmers in the mountains with rainfed land experience a complex process of socio-economic transformation [1]. In fact, according to Boomgaard's records, since the 19th century, various types of plants produced by mountain 
farming systems were economically superior commodities [2]. In a historical study, Peter Boomgaard also found data that the initial settlement in the Java highland region was an attempt to find new economic sources in the form of cultivation of horticulture and plantation commodities. These commodities become commodities to meet market needs so that production requires an increasing workforce [3].

In the past two decades, farmers on the slopes of the west side of Mount Merbabu, precisely in the village of Kenalan, Pakis Subdistrict has turned their agricultural land into horticulture farms. In particular, farmers are beginning to seek potato farming to replace tobacco as a source of cash crop. Changing plant species from tobacco to potato is an interesting phenomenon because the anthropological study conducted by Hery Santoso shows that potato farming systems in Dieng have produced complicated social problems. Farmers face high ecological and social risks because they intersect with the problems of marginalization and exclusion of weak social classes [4]. Therefore this paper seeks to answer the question why farmers on the slopes of Mount Merbabu change their farming systems.

\section{Research Method}

The research was conducted in Pakis Sub-district, Magelang Regency, Central Java Province. The location of the village is on the south side of the slope of Mount Merbabu with a height between 900 - 1200 masl. The location of the village is directly adjacent to the Gunung Merbabu National Park area.

Data collection in this study used qualitative methods with ethnographic perspectives. Data was obtained through participative observation to witness what happened, listen to what was said, and ask questions through formal and informal interviews. Thus researchers find interpretation to understand the social meaning of their activities and experiences in the social settings of society in a reasonable manner [5]

\section{Result and Discussion}

\subsection{Agricultural Character in Kenalan Village}

Agricultural land in Kenalan village is in a slope between 30-50 degrees. With this slope, agricultural land is created in terracing plots with the area of each plot ranging from 750 1250 square meters. The arable land area per household ranges from $750-1500$ square meters. Ownership of arable land is divided into several categories. The first is private land, land with full ownership status by individuals. This land is usually owned by inheritance or buying and selling. Rental land, is land that is worked on by farmers with working status. Land ownership is in individuals or village cash land called bengkok. Renting is based on a certain period of time in accordance with the agreement between the cultivator and the land owner. Mortgage land is arable land obtained because of a borrowing and lending transaction between land owners and cultivators. The value of pledges is determined by using a comparison to the price of gold, or beef. Land prices are converted to gold prices or beef prices at the time the transaction takes place. When the mortgaged land is returned, the land owner must return the money worth the price of gold or beef at the time of return transaction. For example, the land pawned for IDR. 10,000,000, the nominal is converted to the price of gold per gram. If the price of gold is IDR. 400,000 per gram, the mortgage value of the land is 
25 grams of gold. When one day the land is asked, the land owner must return the money worth the price of gold weighing 25 grams. The price of gold and beef on the market always increases so that if it is terminated, the price of the land will be greater compared to the price of the previous mortgage.

Available agricultural land is rainfed land with rainfall of 105 days per year. The wet season lasts from November to May. Farmers in Kenalan village are currently planting various types of vegetable plants in the form of celery, leeks, carrots, broccoli, cabbage, tomatoes, mustard greens, pumpkins, beets, and potatoes. The land is planted continuously without giving pause time. Vegetables are grown with an intercropping system. In one field there are on average three types of vegetables that grow together. The age of the plants that can be harvested is on average of 70-90 days, depending on the type and fertility of the plants. With an intercropping system, every week farmers can harvest vegetables according to the order of planting. When one type of plant has been harvested, new plants are planted immediately between the previous plants. Thus, every week farmers can harvest according to the age of the plants.

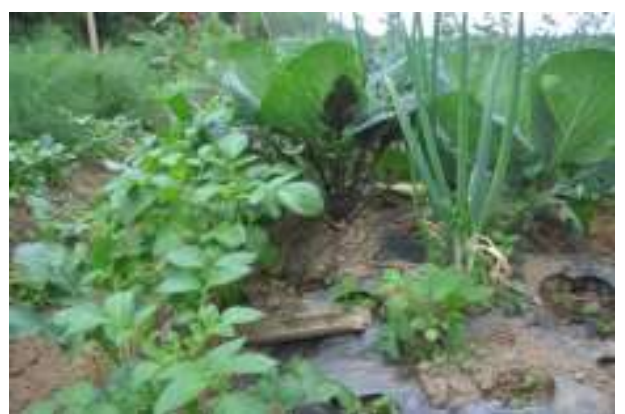

Fig. 1. Intercropping system. Farmer planting potato, beetroot, broccoli, and spring onion at the one field

The intercropping system is a strategy for crop diversification so that it can increase agricultural productivity. Intercropping is one way to develop more efficient intensive agriculture [6]. With an intercropping system, farmers can get regular income to meet their daily household needs.

On the other hand, the increasing intensity of land management has implications for the increasing capital and labor inputs. Vegetable species require daily labor input to control plant growth, from weeding to grass, spraying pesticides, fertilizing, to harvesting. Labor requirements increase during planting, and harvesting. Whereas during the treatment period it can be carried out by family labor. Sources of labor from within the village can still be sufficient for labor needs. Even though each household works on their own land, farmers whose land is narrow still have energy to work for other farmers who have wider land as laborers. The wages of agricultural workers range from Rp. 50,000 - Rp. 70,000 per day depending on the type of work to be completed.

\subsection{Agriculture Changes in Kenalan Village}

The types of plants planted by farmers in Kenalan village are now different from those planted a decade ago. At that time the main types of plants were cabbage, corn, and tobacco. On the sidelines of the three plants are tomatoes, carrots, chives, and celery. The yields of cabbages, tomatoes carrots, celery, and leeks are a source of income for daily needs. Corn 
yields are used for food supplies. Tobacco harvesting is an expectation to get large amounts of money so that it can meet greater needs of the family such as building a house. But nowadays, farmers no longer plant corn. The vegetable crops now can be used to meet the needs of rice all the time so that farmers no longer need to plant corn. Tobacco can still be found even though in very small quantities and only planted on the edge of the land. Tobacco yields are not for sale but are consumed by the farmers themselves as cigarettes. To get large amounts of money, farmers rely on potato yields. If in the past, farmers got large sums of money from tobacco harvests, at present they are replaced by potato yields. Darnomo, one of the farmers said "in the past, to earn money around 5 million rupiah, farmer must waiting for tobacco harvest in 5-6 month. At this time, by planting potato, farmer could earn money by potato harvest in 80 days. In optimal condition, every $1000 \mathrm{~m} 2$ of land can produce potato around $1,5-2$ ton. If the price of potato is $9.000 / \mathrm{kg}$, farmer will earn money around $13-18$ million rupiah. The expense for seed, labor, fertilizer, and pestiside is around 1-2 million rupiah. So farmer choose planting potato than tobacco because the result is differ greatly between potatoes and tobacco "(interview with Darnomo, 2019)

Farmers in the village of Kenalan began planting potatoes around the year of 2000. The planting started with the use of Special Allocation Funds (DAK) from the government. The funds were used by Kenalan Village farmers to develop potato farming. Through farmer groups, the funds were used to develop new varieties of potato seeds to be cultivated in Kenalan village. From this project, many Kenalan villagers started to grow new varieties of potatoes. There are three types of potatoes grown today, namely Glanula, Super King, and Atlantic. Glanula is the most widely grown type of potato. Initially potato seeds are obtained from West Java with the 3rd generation seed quality category (G3). But now the seeds are obtained from setting aside selected crops and then stored for seedlings. So they plant potatoes with G4-G8 seed quality. The renewal of G3 quality seeds will only be re-done after the yields have been greatly reduced. The G3 quality potato seeds are currently obtained by ordering from known seedlings, while the G4 quality seedlings can be obtained from the nearest seed seller in the Kaponan area.

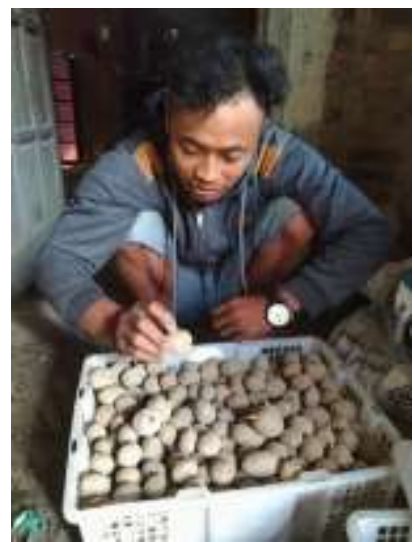

Fig. 2. Potato seeds those are ready to be planted. Farmers select their own potato yields, which are prepared for seedlings

The presence of potato plants brought changes in agricultural agroecosystems in Kenalan village. Potatoes are the main commodities that provide high income for Kenalan villagers. With a plant age of 80 days and the selling price starting from $\mathrm{Rp} .9,000 / \mathrm{kg}$, the potato 
commodity becomes a very quick source of cash, especially when compared to previous sources of cash, tobacco, which reaches 4-6 months. The transition of commodity types from tobacco to potatoes is a form of agroecosystem transformation that takes place in mountainous regions. Roudhotun Arbangiyah in a historical study of the development of potato plants in Sembungan Dieng explained that since the introduction of potatoes in Indonesia by the Dutch in 1811 in Berastagi, North Sumatra, potato plants were expanding to Kerinci (Jambi), Pangalengan (West Java), Dieng (Central Java), Tengger (East Java), and Toraja (South Sulawesi). Especially in Dieng, the presence of potatoes shifted the popularity of tobacco commodities, which had previously become a staple crop [7].

\section{Conclusion}

Social transformation is taking place in the Kenalan village community. The presence of potato commodities brings a change in the orientation of agriculture from meeting the subsistence needs or food crop to generating much money or cash crop. The transition from tobacco to potato commodities is not solely an effort by farmers to acquaint themselves with capturing household economic opportunities, but the change provides a picture of the phenomenon of market strength that can change agricultural orientation. The opening of market access has made farmers in Kenalan Village not worry about their resilience because they are always provided by the market. So the main orientation is to generate cash from agricultural production. But of course its sustainability needs to be questioned because of the very dynamic nature of the market.

\subsection{Acknowledgments} 2019.

This research is part of the lecturer research project, which is funded by DIPA FIS UNNES

\section{References}

[1] T. M. Li, Proses Transformasi Daerah Pedalaman di Indonesia. Yayasan Obor Indonesia, 2002.

[2] P. Boomgaard, "Jagung dan Tembakau di Dataran Tinggi Indonesia, 1600-1940," 2002.

[3] P. Boomgaard, M. F. Sardjono-Soesman, K. S. Toer, and S. M. Abdi, Anak jajahan Belanda: sejarah sosial dan ekonomi Jawa, 1795-1880. Djambatan: Koninklijk Instituut voor Taal-, Land-, en Volkenkunde (KITLV .., 2004.

[4] H. Santoso, "Bertani itu Berjudi: Ketika Mekanisme Pasar Bias Spekulasi." Universitas Gadjah Mada, 2015.

[5] J. Brewer, Ethnography. McGraw-Hill Education (UK), 2000.

[6] M.-J. Qiu and L. Li, "Perspectives for intercropping in modern agriculture," EC Agric. $E C O$, vol. 1, pp. 1-2, 2016.

[7] R. Arbangiyah, "Perubahan Pola Pertanian Rakyat di Desa Sembungan Dataran Tinggi Dieng," Skripsi Univ. Indones., 2013. 
